\title{
Wandel im Gesundheitswesen: Analyse der Auswirkungen auf Ärzte und Patienten am Beispiel der Ukraine
}

\section{Effects of Changes in Healthcare on Doctors and Patients using the Example of Ukraine}

\author{
Autoren \\ Yevgen Bogodistov', Fynn Malte Reck' ${ }^{1}$, Jürgen Moormann¹, Oleksandr P. Krupskyi²
}

Institute

1 ProcessLab, Frankfurt School of Finance \& Management, Frankfurt a.M.

2 Faculty of Economics, Oles Honchar Dnipro National University, Dnipro, Ukraine

\section{Schlüsselwörter}

Burnout, Gesundheitsreform, Patientenzufriedenheit, Prozessinnovation, Strukturreform

\section{Key words}

burnout, health care reform, patient satisfaction, process innovation, structural reform

\section{Bibliografie}

DOI https://doi.org/10.1055/a-0894-4775

Gesundheitswesen 2019; 81: 1-6

(c) Georg Thieme Verlag KG Stuttgart · New York

ISSN 0941-3790

\section{Korrespondenzadresse}

Prof. Dr. Jürgen Moormann

ProcessLab

Frankfurt School of Finance \& Management

Adickesallee 32-34

60322 Frankfurt a.M.

j.moormann@fs.de

$\circledast$ Den Anhang Tab. 1 und Tab. 2 finden Sie online unter https://doi.org/10.1055/a-0894-4775

\section{ZUSAMMENFASSUNG}

Hintergrund Das Gesundheitswesen befindet sich weltweit im Umbruch. Dieser hat nicht nur Auswirkungen auf die Organisation von Krankenhäusern, Arztpraxen, Pflegeeinrichtungen usw., sondern auch auf die beteiligten Personen und Personengruppen. Welche Auswirkungen der Wandel für Ärzte und Patienten hat, wird am Beispiel einer umfassenden Gesundheitsreform in der Ukraine untersucht.

Methoden Die Analyse basiert auf einer empirischen Erhebung, die bei Ärzten in 2 Städten der Ukraine durchgeführt wurde. Auf Basis des Job Demands-Resources Model wurden
Hypothesen entwickelt, die anhand eines Strukturgleichungsmodells überprüft worden sind. An der Befragung haben 178 Familienärzte ( $81 \%$ der Grundgesamtheit) teilgenommen. Ergebnisse Die Untersuchung zeigt einen klaren Zusammenhang zwischen den organisationalen Herausforderungen (zusätzliche Aufgaben, struktureller Wandel, neue Prozesse) und ihren psychologischen Folgen (z. B. Burnout). Letztere wirken sich u. a. negativ auf die Zusammenarbeit der Ärzte in Kliniken aus, was wiederum die Zufriedenheit der Patienten beeinträchtigt.

Diskussion und Schlussfolgerung Der Wandel im Gesundheitswesen ist unausweichlich. Das Beispiel der Ukraine zeigt, dass Offenheit der Kliniken für Wandel die Wahrscheinlichkeit für Burnout von Ärzten reduziert und letztlich die Patientenzufriedenheit erhöht. Daher sind Ansätze des Prozessmanagements, die dazu beitragen, Offenheit in Organisationen zu erzeugen, in Zeiten starken Wandels dringend zu empfehlen.

\section{ABSTRACT}

Background The health care sector is experiencing a drastic transition all over the world. This has an impact not only on the way hospitals, clinics, special-care homes etc. are organized, but also on patients, personnel and other stakeholders involved. The consequences of changes for both physicians and patients are investigated using a comprehensive health care reform in Ukraine as an example.

Methods The analysis is based on empirical data collected from general physicians in 2 Ukrainian cities. Based on the Job Demands-Resources Model, we developed a set of hypotheses and tested them using the structural equation modelling technique. A total of 178 general physicians ( $81 \%$ of the approached population) participated in the study.

Results Our investigation reveals a clear relationship between the organizational job demands (additional tasks, structural changes, new processes) and their psychological effects (e. g., burnout). The latter have a negative impact on cooperation of physicians in hospitals leading to lower patient satisfaction.

Discussion and Conclusions Change in health care is inevitable. The example of Ukraine shows that openness of hospitals towards change reduces the probability of physicians' burnout and, eventually, increases patient satisfaction. We strongly suggest applying the process management approach in order to increase openness to change, especially in turbulent times. 


\section{Diskussion und Schlussfolgerung}

Die Autoren bestätigen, dass kein Interessenkonflikt besteht.

\section{Literatur}

[1] Boerner S, Dütschke E. The impact of charismatic leadership on followers' initiative-oriented behavior. Health Care Manage Rev 2008; 33: $332-340$

[2] Gilbert S, Laschinger HKS, Leiter M. The mediating effect of burnout on the relationship between structural empowerment and organizational citizenship behaviours. J Nurs Manag 2010; 18: 339-348

[3] Schneider J, Kaplan SH, Greenfield S et al. Better physician-patient relationships are associated with higher reported adherence to antiretroviral therapy in patients with HIV infection. J Gen Intern Med 2004; 19: 1096-1103

[4] Ashford S]. Individual Strategies for Coping with Stress during Organizational Transitions. J Appl Behav Sci 1988; 24: 19-36

[5] Schweiger DM, Denisi AS. Communication with Employees Following a Merger: A Longitudinal Field Experiment. Acad Manage J 1991; 34: 110-135

[6] Wanberg CR, Banas JT. Predictors and outcomes of openness to changes in a reorganizing workplace. J Appl Psychol 2000; 85: $132-142$

[7] Haines VA, Hurlbert JS, Zimmer C. Occupational Stress, Social Support, and the Buffer Hypothesis. Work Occup 1991; 18: 212-235

[8] Rhoades L, Eisenberger R. Perceived organizational support: A review of the literature. J Appl Psychol 2002; 87: 698-714

[9] Demerouti E, Bakker AB, Nachreiner F et al. The job demands-resources model of burnout. J Appl Psychol 2001; 86: 499-512

[10] Maslach C, Jackson SE, Leiter MP et al. Maslach Burnout Inventory: Manual. Consulting Psychologists Press; Palo Alto: 1986

[11] Bakker AB, Demerouti E. The Job Demands-Resources model: state of the art. Journal of Managerial Psychology 2007; 22: 309-328

[12] Demerouti E, Bakker AB, Nachreiner $F$ et al. A model of burnout and life satisfaction amongst nurses. J Adv Nurs 2000; 32: 454-464

[13] Bakker AB, Demerouti E, de Boer E et al. Job demands and job resources as predictors of absence duration and frequency. J Vocat Behav 2003; 62: 341-356

[14] Hobfoll SE. Conservation of resources. A new attempt at conceptualizing stress. Am Psychol 1989; 44: 513-524

[15] Jungbauer ], Ehlen S. Stressbelastungen und Burnout-Risiko bei Erzieherinnen in Kindertagesstätten: Ergebnisse einer Fragebogenstudie. Gesundheitswesen 2014; 76: 1-6

[16] Hobfoll SE, Freedy JR. The Availability and Effective Use of Social Support. J Soc Clin Psychol 1990; 9: 91-103

[17] Baltes PB. On the incomplete architecture of human ontogeny: Selection, optimization, and compensation as foundation of developmental theory. Am Psychol 1997; 52: 366-380

[18] Semlitsch T, Abuzahra M, Stigler F et al. Qualitätsindikatoren für Primary-Health-Care-Einrichtungen in Österreich. Gesundheitswesen 2017 Online-Publikation 
[19] Hobfoll SE, Shirom A. Conservation of resources theory: Applications to stress and management in the workplace. In: Handbook of organizational behavior. Golembiewski RT. Ed.Marcel Dekker; New York, NY, US: 2001: 57-80

[20] Bakker AB, Demerouti E, Verbeke W. Using the job demands-resources model to predict burnout and performance. Hum Resour Manage 2004; 43: 83-104

[21] Shanafelt TD, Bradley KA, Wipf JE et al. Burnout and Self-Reported Patient Care in an Internal Medicine Residency Program. Ann Intern Med 2002; 136: 358

[22] Allen J, Jimmieson NL, Bordia P et al. Uncertainty during Organizational Change: Managing Perceptions through Communication. Journal of Change Management 2007; 7: 187-210

[23] Möltner H, Leve J, Esch T. Burnout-Prävention und mobile Achtsamkeit: Evaluation eines appbasierten Gesundheitstrainings bei Berufstätigen. Gesundheitswesen 2018; 80: 295-300

[24] Hobfoll SE. The Influence of Culture, Community, and the Nested-Self in the Stress Process: Advancing Conservation of Resources Theory. Appl Psychol 2001; 50: 337-421

[25] Kristensen TS, Borritz M, Villadsen E et al. The Copenhagen Burnout Inventory: A new tool for the assessment of burnout. Work \& Stress 2005; 19: 192-207
[26] Vorhies DW, Morgan NA. Benchmarking Marketing Capabilities for Sustainable Competitive Advantage. J Mark 2005; 69: 80-94

[27] Hair JF, Black WC, Babin B] et al. Multivariate Data Analysis. Pearson Education Limited; Harlow, Essex, UK: 2014

[28] Hu L, Bentler PM. Cutoff criteria for fit indexes in covariance structure analysis: Conventional criteria versus new alternatives. Struct Equ Modeling 1999; 6: 1-55

[29] Richardson HA, Simmering MJ, Sturman MC. A Tale of Three Perspectives. Organizational Research Methods 2009; 12: 762-800

[30] Hayes AF. Introduction to Mediation, Moderation, and Conditional Process Analysis. Second Edition A Regression-Based Approach. Guilford Press. Im Internet: https://www.guilford.com/books/ Introduction-to-Mediation-Moderation-and-Conditional-ProcessAnalysis/Andrew-Hayes/9781462534654

[31] Schmelzer H], Sesselmann W. Geschäftsprozessmanagement in der Praxis. Kunden zufrieden stellen-Produktivität steigern-Wert erhöhen, Hanser 2008

[32] Womack JP, Jones DT. Lean Thinking: Banish Waste And Create Wealth In Your Corporation. Simon and Schuster; 2013

[33] Pande P, Neuman R, Cavanagh R. The Six Sigma Way. McGraw Hill; 2000

[34] De Koning $\mathrm{H}$, Verver JPS, van den Heuvel J et al. Lean six sigma in healthcare. J Healthc Qual 2006; 28: 4-11 